\title{
Regional and State Association News
}

\section{Midwest Political Science Association}

\section{Convention News}

The Midwest Political Science Association held its 54th annual meeting, April 18-20, 1996 at the Palmer House Hilton in Chicago. The conference was attended by nearly 2,000 individuals, making it the second largest meeting in the association's history. The program committee, chaired by Charles Franklin, University of Wisconsin, organized 282 panels and one poster session of graduate student research.

The 55th annual meeting will be held April 10-12, 1997 at the Palmer House Hilton. The program will be organized by Mary Dietz and John Freeman of the University of Minnesota. Their committee will have 23 sections and each will feature a panel addressing the program theme: "Political Science: A Discipline Too Divided?' The call for papers can be found in the "Upcoming Conferences" section of $P S$. The deadline for proposals is September 15, 1997.

\section{Elections}

Arlene Saxonhouse, University of Michigan, became president of the association at the conclusion of the annual business meeting. She presented a plaque to and thanked James Stimson, University of Minnesota, for his service as president and his contributions to the discipline.

At the annual business meeting, the following political scientists were elected to serve on the association's executive council: President-elect: Harold Spaeth, Michigan State University; VicePresident (1996-98): Paul Allen Beck, Ohio State University; Council Members (1996-99): Linda Bennett, Wittenberg University, Nancy Burns, University of Michigan,
Gary King, Harvard University, Bert Kritzer, University of Wisconsin-Madison, and Kenneth Williams, Michigan State University.

Nominations are now being sought for president-elect, vicepresident, and five council offices to be elected during the 1997 meeting. Nominations with vita should be sent to Gregory Caldeira, Department of Political Science, Ohio State University, Columbus, $\mathrm{OH}$ 43210; Phone: (614) 292-4476; Fax (614) 292-1146; E-mail: gcaldeir@ magnus.acs.ohio-state.edu.

\section{New By-Laws}

During the annual business meeting, the membership approved new by-laws for the association. The by-laws were revised to be consistent with the reorganization of the association as an incorporated entity. The association was officially incorporated in February, 1996, in the state of Illinois. Anyone who would like a copy of the new bylaws should contact the MPSA offices in Chicago: $6525 \mathrm{~N}$. Sheridan Road, Chicago, IL 60626 or e-mail: jpeliss@luc.edu.

\section{Awards}

The following awards were presented to individuals who presented the best papers at the previous year's meeting:

Pi Sigma Alpha Award for best paper, 1995. Recipients: Scott Ainsworth, University of Georgia, Patrick Fett, University of Memphis, Itai Sened, Tel Aviv University; Paper: "Implications of Turnover and Term Limits on Institutional Stability"; Committee: William Bianco (chair), Renee Smith, and Virginia Gray.

The Westview Press Award for best paper written by a graduate student, 1995. Recipient: Gary McKissick, University of Michigan;
Paper: "Interests, Issues, and Emphases: Lobbying Congress and the Strategic Manipulation of Issues Dimensions"'; Committee: Jim Kuklinski (chair), Elizabeth ThiessMorse, and Michael Berkman.

Sophonisba Breckinridge Award for best paper written about women and politics, 1995. Recipient: Nancy Burns, University of Michigan; Paper: "Gender, Endogeneity, and Political Participation"; Committee: MPSA Committee on the Status of Women: Liane Kosaki (chair), Vicki Hesli, and Lettie McSpadden.

Sprague Award for a paper with an outstanding quantitative analysis of a substantive problem. Recipients: R. Michael Alvarez, California Institute of Technology and John Brehm, Duke University; Paper: "Are Americans Ambivalent Towards Racial Policies?',; Committee: Chris Achen (chair), Duncan Snidal, Carol Kohfeld.

\section{Editor Search}

MPSA President Arlene Saxonhouse announced the formation of a search committee to recommend the selection of a new editor for the American Journal of Political Science. The association is seeking a qualified individual who will edit the journal from January 1, 1998 through December 31, 2001. The search process will be conducted during the next 12 months, with an appointment to be announced during the 1997 meeting of the MPSA.

Nominations and self-nominations should include a letter of interest, with a statement of goals for the journal, and a curriculum vitae should be sent to:

John Pelissero, Executive Director Midwest Political Science

Association 6525 N. Sheridan Road Chicago, IL 60626

E-mail: jpeliss@luc.edu 
The search committee includes:

Arlene Saxonhouse, University of Michigan, Chair

James Stimson, University of Minnesota

Harold Spaeth, Michigan State University

Duncan Snidal, University of Chicago

\section{Journal Change}

Upon the recommendation of Kenneth J. Meier, University of Wisconsin-Milwaukee, editor of the American Journal of Political Science, beginning in 1997 the journal will be published in January, April, July, and October. This change will result in a more efficient production process and schedule for the journal.

\section{New England Political Science Association}

Over two hundred participants attended the 48th Annual Meeting of the New England Political Science Association, held on May 3-4 in Springfield, Massachusetts. NEPSA President Jerome Mileur and Program Chair Jeffrey Sedgwick, both of the University of Massachusetts, put together a slate of more than 45 panels and convened plenary sessions with guest speakers William A. Bulger, former Massachusetts state senate president and new president of the University of Massachusetts system, and Bruce Freed, former journalist and president of Integrated Strategies, a Washington consulting firm.

Awards for the best papers given at the 1995 meeting went to Diana Evans (Trinity College), who won the John C. Donovan Prize for "The NAFTA Sale: Presidential Vote-Buying and its Effects,' and to Laura Jensen (University of Connecticut), who won the Robert C. Wood Prize for "Early American Origins of Entitlement Policies."

The association's 1997 meeting will be held on May 2-3 at the Radisson Hotel in New London,
Connecticut. Inquiries can be directed to NEPSA president Barbara Craig, Department of Government, Wesleyan University, Middletown, Connecticut 06457.

\section{Southwestern Social Science Association}

Following is the list of officers for political science that took seats following the Seventy-sixth Annual Meeting of the Southwestern Social Science Association in Houston, Texas. Patricia Hurley, President, Texas A\&M University; Robert Stein, President-Elect, Rice University; Harold F. Bass, SecretaryTreasurer, Quachita Baptist University; Cynthia Opheim, Vice President and Program Chair, Southwest Texas State University.

The 1997 Council will include: Mitchell Rice, Louisiana State University; Florence Gould, Southwestern University, and Richard Herrera, Arizona State University.

\section{APSA's Membership DiReCTORY is COMING!}

\section{DO YOU NEED TO UPDATE YOUR MEMBERSHIP INFORMATION?}

In 1997 the APSA will print the new Membership Directory from the information stored in our database as of November 15, 1996. It is up to you to make sure we have your most current data. What we maintain is reported to you annually on your Membership Renewal Form, which you update and return to us with your dues payment. If you are a new member, if your information has changed, or if you want to add something new, please contact us with your changes by November 15, 1996. There is a form you can use for this purpose on page 632 . 